\title{
Peranan Kepala Desa dan Badan Permusyawaratan Desa dalam Pembangunan Desa Di desa Galanti Kecamatan Wolowa Kabupaten Buton
}

\author{
L. M. Ricard Zeldi Putra
}

Fakultas Hukum, Universitas Muhammadiyah Buton, Indonesia Korespondensi: laodericard@gmail.com

\begin{tabular}{|c|c|}
\hline Info A & Abstrak \\
\hline $\begin{array}{c}\text { Disetujui } 25 \mathrm{Mei} \\
2021\end{array}$ & $\begin{array}{l}\text { Studi ini bertujuan untuk mendeskripsikan peranan aparatur desa dalam } \\
\text { menjalankan fungsinya sebagai eksekutor pengambil keputusan dan } \\
\text { pemberi pelayanan bagi kepentingan kesejahteraan desa, di Desa Galanti, } \\
\text { Kecamatan Wolowa, Kabupaten Buton. Adapun metode yang digunakan } \\
\text { adalah metode kualitatif dengan pendekatan sosiologis. Pengambilan data } \\
\text { penelitian dilakukan dengan depth interview, observasi dan dokumentasi. } \\
\text { Studi ini menunjukkan bahwa Aparatur Pemerintah Desa telah } \\
\text { menjalankan peranannya dengan baik yang mana baik kepala desa } \\
\text { maupun BPD berupaya memberikan dukungan yang terbaik kepada }\end{array}$ \\
\hline $\begin{array}{l}\text { Keywords: } \\
\text { Aparatur Desa, } \\
\text { Peranan, Desa } \\
\text { Galanti, } \\
\text { Masyarakat Desa, } \\
\text { Kesejahteraan }\end{array}$ & $\begin{array}{l}\text { masyarakat desa di berbagai bidang sesuai dengan kapasitas dan } \\
\text { kapabilitas yang telah ditentukan. Aparatur Pemerintah Desa memberikan } \\
\text { pelayanan seperti meningkatkan taraf hidup masyarakat dengan } \\
\text { meningkatkan pendapatan, menghubungi dan mendatangkan pelayanan } \\
\text { pertanian dan kesehatan sebagai bentuk kepedulian terhadap berbagai } \\
\text { permasalahan yang dihadapi warganya. }\end{array}$ \\
\hline $\begin{array}{l}\text { (C) } 2019 \text { Universitas } \\
\text { Muhammadiyah } \\
\text { Buton } \\
\text { Under the license } \\
\text { CC BY-SA } 4.0 \\
\text { cC) }\end{array}$ & $\begin{array}{l}\text { Abstract } \\
\text { The aim of this study is to identify the role of village officials in carrying out } \\
\text { their duties as executors of decision-makers and service providers for the } \\
\text { benefit of village welfare in Galanti Village, Wolowa District, Buton } \\
\text { Regency. The method used is a qualitative method with a sociological } \\
\text { approach. The study data was gathered by in-depth interviews, } \\
\text { observation, and reporting. This study demonstrates that the Village } \\
\text { Government Apparatus has performed well in its function, in which both } \\
\text { the village head and the BPD aspire to provide the best service to village } \\
\text { populations in various fields based on their determined capacities and } \\
\text { capabilities. As a means of consideration for the different issues faced by } \\
\text { its residents, village government leaders offer services such as raising the } \\
\text { community's quality of life by raising wages, engaging and bringing in } \\
\text { agricultural and health facilities. }\end{array}$ \\
\hline
\end{tabular}

\section{Pendahuluan}

Penyaluran dana desa merupakan cerminan dari hak desa untuk menjalankan kedaulatannya dalam rangka mensejahterakan masyarakat desa. Keberagaman, inklusi, demokratisasi, dan pemberdayaan masyarakat adalah 
factor-faktor yang berkontribusi terhadap pembangunan desa. Dalam skema kawasan pembangunan, posisi aparatur desa ditingkatkan dalam memberikan pelayanan kepada penduduk, serta mempercepat pembangunan dan pertumbuhan daerah (Surjadi, 1995).

Berdasarkan Peraturan Pemerintah Nomor 72 Tahun 2005 bahwa pembiayaan pelaksanaan otonomi di tingkat desa bersumber dari Anggaran Pendapatan dan Belanja Desa dan Bantuan Pemerintah Desa dengan tujuan untuk mempercepat pembangunan yang merata dan mandiri. Pelaksanaan otonomi daerah ini semakin nyata dengan implementasi UU no 6 tahun 2014 yang menggolontorkan bantuan dana desa sebesar Rp.1,5 M pertahunnya. Pengaalokasian aggaran dana desa yang cukup besar tersebut menuntut aparatur desa mengelola anggaran tersebut secara transparan demi kemakmuran warga masyarakat yang dipimpinnya.

Kebebasan aparatur desa dalam mengelola alokasi anggaran yang begitu besar memunculkan pertanyaan dari masyarakat luas mengenai kesiapan serta potensi penyalahgunaan pengelolaan anggaran oleh aparatur desa. Pertanyaan ini menuntut isu akuntabilitas dari apartur desa dalam melaksanakan fungsinya untuk mensejahterakan masyarakatnya (Astuti, 2013).

Peranan kepala desa yang menjalankan fungsi pelaksanaan dan BPD dengan fungsinya sebagai badan pengawas, memiliki kedudukan yang sangat penting dalam menjalankan program pemabangunan desa (Roza \& Arliman, 2017).

Program pembangunan desa merupakan suatu usaha terencana yang bersifat jangka panjang, terukur dan memiliki dampak dalam peningkatan kesejahteraan masyarakat desa. Untuk mencapai tujuan ini, kepala desa sebagai pemangku kebijakan pertama harus mampu menjalankan program-programnya sesuai amanat undang-undang. Pasal 7 ayat (3) menyatakan bahwa pengembangan kapasistas di desa di swakelola oleh desa atau badan kerjasama antar desa, sehingga jelas, bahwa kepala desa, memiliki peran sebagai motor penggerak pemabangunan pada wilayah/ desa yang dipimpinnya.

Sebagai wilayah administrative terkecil dalam suatu negara, pembangunan di desa belum sepenuhnya berjalan secara merata. Hal ini disebabkan oleh banyak factor, salah satunya adalah kurang profesionalnya sumber daya manusia yang mengelola pembangunan di suatu desa. Berdasarkan observasi awal Di Desa Galanti Kecamatan Wolowa Kabupaten Buton, kepala desa maupun BPD belum menunjukkan perannanya secara optimal dalam menjalankan fungsinya sebagai perpanjangan tangan pemerintah pusat dalam upaya melakukan percepatan pembangunan di desanya. Hal ini dapat tercermin dari ketidak jelasan dari aparatur desa dalam mengupayakan jadwal rapat musyawarah Bersama untuk menampung keluhan dan aspirasi masyakat desa yang dipimpinnya, yang menyebabkan program-program pembangunan desa seringkali berasal dari satu pihak dan tidak menyentuh kebutuhan dasar masyarakat desa.

\section{Metode Penelitian}

Penelitilan ini menggunakan pendekatan sosilogis empiris yang berfokus pada pengkajian hukum berdasarkan realitas atau perilaku yang terjadi dalam suatu masyarakat. Penelitian jenis ini diawali dengan studi data sekunder berupa 
dokumen-dokumen pendukung terkait objek penelitian yang diangkat untuk kemudian dilanjutkan dengan penelitian pada data primer dilapangan atau masyarakat (Soekanto, 2003).

Jenis penelitian ini adalah jenis penelitian kualitatif dengan menggunakan analisis data deskriptif yang berfokus pada fenomena yang terjadi dilapangan (Sugiyono, 2010). Adapun penelitian ini bertujuan untuk menggali lebih dalam mengenai peranan dan factor-faktor penghambat aparatur desa di Desa Galanti Kecamatan Wolowa Kabupaten Buton dalam melaksanakan tupoksinya sebagai perpanjangan tangan pemerintah pusat dalam menciptakan kesejahteraan bagi masyarakat desa diwilayah administratifnya sesuai dengan Undang-Undang No. 6 tahun 2014 tentang Desa.

\section{Hasil Penelitian dan Pembahasan}

Desa merupakan wilayah administrative terkecil suatu negara yang terbentuk dari suatu kesatuan masyarakat hukum yang memiliki batas-batas wilayah tertentu dalam mengatur segala administrasi negara untuk kepentingan masyarakat setempat. Desa Galanti secara geografis terletak di kecamatan Wolowa kabupaten Buton, merupakan salah satu desa yang mekar pada tahun 2011. Penetapan sebagai desa galanti melalui Peraturan Daerah (Perda) Kabupaten Buton No. 30 Tahun 2011 Tentang Pembentukan Desa Galanti Kecamatan Wolowa.

Dari cerita masyarakat beredar, bahwa penamaan desa diambil dari nama sebuah pohon yaitu "Galanti". Cerita saat itu, bahwa di Kampung Galanti ada pohon besar di kali Sokoa yang sudah roboh dan bangkai kayu tersebut sudah berusia ratusan tahun dan sampai hari ini masih utuh, dengan kekalnya bangkai pohon Galanti sehingga melekat menjadi nama kampung turun temurun hingga sekarang ini. Galanti merupakan Kampung yang terbentuk sejak zaman penjajahan dengan status berupa Kampung dalam wilayah administrative Desa Wolowa. Namun, seiring dengan pertambahan jumlah penduduk dengan komleksitas kebutuhan yang semakin bertambah maka pada tahun 2011 kampung galanti secara defintif dimekarkan menjadi satu desa tersendiri, hal ini dilakukan untuk menjamin kemudahan akses terhadap pelayanan urusan pemerintahan \& kemasyarakatan.

\subsection{Pemerintahan dan Program Pembangunan Desa Galanti}

Sesuai dengan peraturan perundang-undangan yang mengatur desa, pemerintahan desa galanti dipimpin oleh seorang kepala desa yang dipilih langsung oleh masyarakatan melalui pemilihan kepala desa (pilkades). Berikut adalah sejarah pemerintahan desa dalam beberapa periode kepemimpinan:

Tabel 4.1 Sejarah Pemerintahan Desa

\begin{tabular}{cclc}
\hline No & PERIODE & NAMA & KETERANGAN \\
\hline 1 & $2011-2015$ & Samsudin & Definitif \\
\hline 2 & $2015-2017$ & La Jamil & Paw \\
\hline 3 & $2017-2018$ & La Nobu Ali & Pelaksana \\
\hline 4 & $2018-2024$ & La Jamil & Definitif \\
\hline
\end{tabular}


Pembangunan Desa di Desa Galanti dapat berjalan dengan baik sesuai Rencana Pembangunan Jangka Menengah Desa (RPJM Des). Dengan banyaknya program pembangunan yang berjalan sesuai perencanaan maka dapat disimpulkan bahwa fungsi kepemimpinan kepala desa dalam menejerial program pembangunan berjalan dengan optimal dan maksimal. Berikut adalah program pembangunan desa galanti dari tahun ke tahun:

\begin{tabular}{|c|c|c|c|}
\hline No & Tahun & Kegiatan Pembangunan & Keterangan \\
\hline 1 & 2009 & Pembangunan jalan Desa & PNPM Mandiri \\
\hline 1 & 2011 & Pembangunan Gedung TK & PNPM Mandiri \\
\hline 2 & 2011 & Pembangunan MCK & PNPM Mandiri \\
\hline 3 & 2012 & Pembangunan SMP & PNPM Mandiri \\
\hline 4 & 2012 & Pembangunan PUSTU & PNPM Mandiri \\
\hline 5 & 2013 & Pembangunan BARUGA & COREMAP \\
\hline 6 & 2010 & Pembangunan SMK SAMIRI & APBN \\
\hline 7 & 2010 & Pembangunan Jalan Tani & APBD \\
\hline 8 & 2015 & Pembanguna Kantor Desa & Dana Desa \\
\hline 9 & 2016 & Pembangunan Jalan lingkar Desa & Dana Desa \\
\hline 10 & 2017 & Pembangunan Jalan Rabat Beton & Dana Desa \\
\hline 11 & 2017 & Pembangunan Jalan Nelayan & APBD \\
\hline 12 & 2017 & Pembangunan Lapangan VOLLY & Anggaran Dana Desa \\
\hline 13 & 2017 & Pembangunan Pagar TK & Dana Desa \\
\hline 14 & 2017 & Pembangunan Kantor Bumdes & Dana Desa \\
\hline 15 & 2017 & Pembangunan air bersih & APBN \\
\hline 16 & 2018 & Pembanguna lapngan footsal & Dana Desa \\
\hline 17 & 2018 & Pembangunan Lampu Jalan & Dana Desa \\
\hline
\end{tabular}

\subsection{Peranan Kepala Desa dan BPD Dalam Pelaksanaan Pembanganan di Desa Galanti}

Pelaksanaan tugas aparatur desa merupakan suatu bentuk tanggung jawab dari aparatur terpilih untuk melakukan pergerakan pembangunan sebagai usaha untuk meningkatkan kesejahteraan mayarakat setempat. Sehingga kepala desa dan BPD dalam menjalankan peranannya didasarkan pada Pembinaan, Pelayanan dan Pengembangan masyarakat desa yang dipimpinnya. Penjabaran peranan aparatur desa dapat di deskripsikan sebagai berikut:

1. Pembinaan Terhadap Masyarakat (Ekonomi, Hukum, Agama dan Kesehatan)

Di bidang ekonomi, upaya untuk mendorong pertumbuhan desa meliputi tiga pihak yaitu pemerintah, swasta, dan masyarakat desa. Tujuannya untuk terus 
meningkatkan kualitas hidup dan kondisi sosial masyarakat pedesaan yang merupakan mayoritas masyarakat Indonesia. Dalam kenyataannya, peran dan intervensi pemerintah tetap dominan dalam perencanaan dan pelaksanaan, serta peningkatan pengetahuan dan kapasitas teknologi warga desa untuk pembangunan desa. Menurut berbagai hipotesis, rahasia kemajuan pertumbuhan desa adalah pengetahuan dan keterlibatan penduduk desa (Wijayanto, 2017). Sementara itu, peningkatan kesadaran kelompok desa akan nilai kegiatan pembangunan sebagai sarana perbaikan kondisi sosial dan peningkatan keterlibatan masyarakat dalam pembangunan sangat bergantung pada kemampuan kepala desa, terutama kepala desa. Berdasarkan wawancara yang penulis lakukan dengan salah satu tokoh masyarakat di Desa Galanti "Mulyadin", beliau menyatakan:

\begin{abstract}
"Masyarakat di desa ini sangat antusias menyambut setiap ada kegiatan yang dapat memberdayakan potensi yang ada di daerah kami. Persoalan hanya terletak kepada bagaimana upaya yang dilakukan oleh kepala desa untuk merangkul tokoh-tokoh masyarakat dalam menggerakkan mereka karena maju tidaknya pembangunan di desa kami sangat bergantung kepada kepemimpinan pemerintah desa atau kepala desa".
\end{abstract}

Di bidang hukum, Pemerintah desa Galanti melakukan pembinaan dengan bekerjasama dengan dinas terkait dan pihak kepolisian yang dimaksudkan agar pemuda dapat memberikan bimbingan kemasyarakatan dan pengentasan anak di lembaga-lemhaga pemasyarakatan anak negara. Contoh, pemuda dan masyarakat mengikuti penyuluhan hukum yang diadakan oleh Fakultas Hukum Universitas Muhammadiyah Buton tentang Penghapusan kekerasan dalam rumah tangga, berkumpul untuk mendiskusikan bahaya akibat narkotika, diberi penyuluhan akihat adanya perkelahian pelajar.

Pembinaan di bidang Agama dilakukan meningkatkan kehidupan beragama di kalangan pemuda dan masyarakat. Contohnya, mengadakan pengajian setiap minggu serta kerja bakti untuk membangun tempat ibadah.

Pertumbuhan bidang kesehatan diarahkan pada terciptanya generasi muda yang stabil, baik fisik maupun psikis, yang mampu berkontribusi bagi kesehatan masyarakat dan lingkungannya. Pemerintah mempromosikan pengenalan pemerintah daerah dengan pembinaan. Pendampingan adalah upaya pemberdayaan daerah otonom melalui pemberian arahan, penyuluhan, penyiapan, pengarahan, dan pengawasan. Pemerintah Desa Galanti bekerja sama dengan BPD memberikan arahan kepada kelompok dengan mengumpulkan anggota untuk menyusun gambaran kegiatan yang perlu dilakukan dan bagaimana pelaksanaannya di daerah. Jika penduduk setuju dan menerima, maka pemerintah desa hanya perlu membimbing dan memberikan arahan bagaimana menangani proyek di bidang pendidikan, kesehatan, sosial budaya, dan ekonomi, serta program pemberdayaan masyarakat di bidang pertanian dan perkebunan.

Jenis pengajaran yang paling aktif adalah bimbingan dalam praktik keagamaan. penyuluhan dan dukungan sosial budaya bagi ibu-ibu PKK. Fasilitasi kegiatan ditindaklanjuti dengan pemberian bantuan alat-alat seni dan ceramah agama yang biasanya didatangkan dari luar desa. sebagaimana yang disampaikan oleh Sumardona S.E., M.M, Ketua BPD di Desa Galanti : 


\begin{abstract}
"Kegiatan yang lelah disusun oleh pemerintah desa untuk melakukan kegiatan pembersihan secara bergotong-royong di tempat ibadah setiap dua minggu sekali merupakan bentuk kepedulian yang ditanamkan untuk memupuk tali silaturrahim dengan sesama warga, dan pengajian yang rutin diadakan setiap minggu yang disertai dengan ceramah agama biasanya banyak dihadiri oleh anak-anak muda. Mungkin tujuan dari pemerintah desa adalah menanamkan pemahaman agama sejak dini kepada generasi muda".
\end{abstract}

Tugas nyata aparatur Pemerintah Desa Galanti bersama BPD juga memberikan penyuluhan kesehatan. Begitu pula di setiap dusun di desa ini perhatian aparat desa di bidang kesehatan memiliki posyandu, di mana setiap bulan anak ditimbang dan diberi pendampingan ibu, baik ibu menyusui maupun nifas, serta disediakan makanan tambahan Di Desa Galanti a POSKESDES (Pos Kesehatan Pemukiman) didirikan, dengan masa balita dini dan pemberian imunisasi, baik Campak, BCG dan DPT, tenaga kesehatan dan pimpinan posyandu diketuai oleh tim penggerak PKK Desa. Bagi yang memiliki Kartu Keluarga dan KTP, lokasi ini untuk pelayanan kesehatan desa gratis.

\title{
2. Pelayanan Terhadap Masyarakat
}

Pemberian pelayanan yang baik kepada masyarakat diharapkan lebih memperhatikan kebutuhan masyarakat, dimana model pengabdian kepada masyarakat telah berubah dari program yang terpusat ke arah pengelolaan yang lebih mementingkan kepuasan masyarakat, sebagai berikut:

a. memberikan penekanan yang lebih besar pada mekanisme pengaturan melalui kebijakan yang mendorong pembentukan keadaan yang mendukung penyediaan layanan publik.

b. Meningkatkan pemberdayaan pemimpin desa dan kota sehingga warga merasakan rasa kepemilikan yang kuat terhadap pusat layanan yang telah dirancang secara kolaboratif.

c. Membangun pasar yang kompetitif untuk layanan semacam itu untuk memastikan bahwa pelanggan memiliki layanan berkualitas tinggi.

d. Berkonsentrasi pada pemenuhan visi, tujuan, prioritas, dan strategi yang berorientasi pada hasil, selaras dengan partisipasi atau keinginan kelompok.

e. Memprioritaskan peluang yang diinginkan oleh penduduk.

f. Menjaga komunikasi terbuka dengan masyarakat dan menerima kekhawatiran tentang program yang disediakannya.

Namun demikian, pelayanan yang diberikan oleh otoritas pemerintah kepada masyarakat juga dituntut untuk: a. Memberikan dasar hukum yang kuat dalam pelaksanaannya; b. Memberikan visi dalam pengambilan keputusan; c. Memiliki tujuan yang sama dalam kehidupan sipil; d. Bertanggung jawab dan terbuka untuk umum; dan e. Memberikan layanan tingkat tinggi kepada masyarakat (Sadu Wasistiono \& Tahir, 2007)

Mengenai cara pemerintah desa melayani masyarakat di Desa Galanti, yaitu dengan menupayakan realisasi aspirasi dan kebutuhan masyarakat, sehingga apabila masyarakat tersebut meisalnya membutuhkan fasilitas dalam perbaikan pertanian maka perangkat pemerintah desa mencarikan jalan keluar dengan melaksanakan program yang tepat untuk perbaikan kondisi pertanian. Kondisi 
yang diuraikan di atas sesuai dengan temuan wawancara yang saya lakukan dengan ketua komunitas petani "La Hidi Tala", di mana penulis menanyakan tentang sifat layanan pemerintah desa di bidang pertanian. La Hidi Tata membuat pernyataan berikut:

"Hasil panen gagal tidak bisa sepenuhnya disebabkan karena kesalahan petani, tetapi pemerintah desa harus juga bertanggung jawab terhadap kegagalan panen karena kurangnya perhatian untuk memberikan jalan keluar bagaimana mengatasi panen yang gagal. karena itu dengan adanya upaya pemerintah desa untuk menghubungi dinas pertanian agar rutin memberikan penyuluhan dan informasi tentang tata cara bertani yang benar dan sebagainya dianggap sangat hermantaat bagi kelangsungan hidup kami" (12 April 2019).

Dari segi efektivitas dan keandalan program pemerintah desa, hal ini terlihat pada pelayanan yang ditawarkan aparat desa kepada masyarakat. Beberapa metrik digunakan untuk menentukan kualitas program ini, antara lain pengetahuan dan kearifan Kepala Desa, BPD, dan aparat Pemerintah Desa lainnya tentang program kemasyarakatan. Seperti kasus untuk semua layanan birokrasi pemerintah, setiap layanan harus mematuhi protokol dan prosesnya sendiri. Prosedur pengabdian kepada masyarakat ini tidak terlepas dari peran Pemerintah Desa dalam mengembangkan badan pemerintahannya, baik secara administratif maupun dalam bidang pembinaan, pengawasan, dan penyuluhan bagi masyarakat Desa (Sunindhi, 1996). Salah satu upaya paling signifikan yang dilakukan oleh Dewan Desa Banga, seperti yang disarankan oleh BPD, adalah pembentukan kotak saran untuk memenuhi berbagai aspirasi yang tertinggal di pintu masuk kantor desa. Berdasarkan temuan wawancara dengan kepala desa, "La Jamil" menyatakan:

"sebagai bentuk kepedulian kami akan berbagai permasalahan yang terjadi pada warga, kami menyediakan kotak saran untuk menampung berbagai keluhan dan aspirasi masyarakat serta berbagai kendala yang dihadapi. Meskipun demikian, dalam berbagai kesempatan ketika ada rembung desa, saya selaku yang dipercayakan memimpin mereka menyampaikan bahwa semua saran dan aspirasi jika bernilai positif akan ditampung dan ditindaklanjuti sesuai dengan skala prioritas dan kemampuan anggaran yang tersedia".

\section{Pengembangan Terhadap Masyarakat}

Efektivitas masyarakat dalam suatu program atau inisiatif, seperti kebijakan pelaksanaan dalam upaya meningkatkan pertumbuhan desa, tidak dapat dibedakan dari dukungan atau keterlibatan masyarakat dalam mematuhi atau menegakkan peraturan yang telah ditetapkan. Dalam situasi ini, hukum terutama mementingkan dua (2) aspek, yaitu pemerintahan desa dan kependudukan itu sendiri. Sekali lagi bagi pemerintah, tujuan atau tugas ini adalah membuat perencanaan tata ruang yang efisien untuk memaksimalkan penggunaan ruang sesuai dengan klasifikasinya dan juga membangun bangunan yang efektif untuk menjaga keindahan desa sekaligus menjaganya tetap bersih dan teratur (Dauwole et al., 2017). Selain pertimbangan tersebut, hal ini juga dimaksudkan sebagai sarana pendapatan desa dalam rangka mendanai pemerintahan dan pertumbuhan, khususnya pengembangan organisasi yang lebih efektif. 
Perencanaan desa harus memiliki tujuan yang jelas untuk memaksimalkan efektivitas dan efisiensi modal yang langka. Di bawah ini adalah beberapa tujuan yang dapat ditetapkan atau dicapai oleh pembangunan desa:

a. Pembangunan ekonomi masyarakat. Pada hakikatnya pertumbuhan ekonomi kerakyatan adalah tentang penguasaan segala potensi ekonomi yang merasuki kehidupan banyak orang melalui penerapan nilai-nilai ekonomi atau prinsip-prinsip ekonomi kerakyatan. Layanan untuk pertumbuhan ekonomi masyarakat yang dapat dikembangkan di desa berikut ini: (1) Pemberdayaan Usaha Kecil Pedesaan, yang meliputi inisiatif seperti menawarkan kredit tanpa bunga. (2) Produksi pertanian dalam arti luas yang bertujuan untuk meningkatkan ketersediaan pangan dan pendapatan produsen, nelayan, dan petani. (3) Dengan membina usaha lokal, kita akan menumbuhkan dan memberdayakan koperasi serta usaha mikro (kecil) dan menengah. (4) tumbuhnya usaha kecil dan utilitas serta jasa untuk pembangunan ekonomi pedesaan. (5) Eksplorasi peluang dan penerapan teknologi yang sesuai untuk mendukung usaha kecil pedesaan.

b. Pembinaan sumber daya manusia secara berkelnajutan. Sumber daya manusia merupakan objek terpenting dalam proses pembangunan desa, yang mana jikan SDMnya secara mental dan jasmani baik dan terampil maka hal ini akan memacu pertumbuhan di sector ekonomi. Adapun program yang dapat dijalankan oleh pemrintah desa dalam menyentuh pembangunan dibidang SDM antara lain: 1) mengupayakan peningkatan Pendidikan, dalam hal ini pembangunan sekolah dengan jenjang Pendidikan yang lengkap; 2) melaksanakan program kesehatan; 3) pembinaan generasi berdasarkan minat dan keterampilannya; 4) program perluasan kesempatan kerja dan pekerjaan; dan lain sebagainya.

c. Pengembangan sumber daya alam dan melestarikan lingkungan hidup agar dapat didayagunakan secara berkelanjutan. Desa Galanti memiliki sumber daya alam yang banyak, yang sangat bermanfaat bagi kehidupan masyarakat Desa, utamanya hasil-hasil perkebunan antara lain Jambu Mette dan Kelapa. Adapun program peningkatan partisipasi masyarakat dalam pengelolaan sumber daya alam dan pelestarian lingkungan dilakukan dengan melaksanakan hal-hal sebagai berikut: (1) melaksanakan program peningkatan pendapatan masyarakat berpenghasilan rendah di daerah kritis; (2) memfasilitasi pelaksanaan program pemberdayaan masyarakat dalam pelestarian lingkungan; dan (3) memfasilitasi pelaksanaan program rehabilitasi.

Dari data lapangan yang diambil melalui wawancara tokoh masyarakat di Desa Galanti, maka ada beberapa hal yang dapat penulis gambarkan mengenai peran aparatur desa Galanti yaitu sehabai berikut:

1) Kepala Desa dan BPD telah berupaya semaksimal mungkin untuk memberikan pelayanan terbaik kepada warga masyarakat desa di berhagai sektor sesuai dengan program yang telah ditetapkan.

2) Bentuk pelayanan yang diberikan oleh aparatur Pemerintah Desa meliputi perbaikan hidup masyarakat dalam nmeningkatkan penghasiłan, menghubungi dan mendatangkan dinas pertanian dan dinas kesehatan sebagai bentuk kepedulian terhadap berbagai masalah yang dihadapi 
warga masyarakatnya dan bekerjasama dengan Fakultas Hukum Universitas Muhammadiyah Buton dalam kegiatan pelatihan pembentukan rancangan peraturan desa dan pendampingan kegiatan pemerintah desa dan BPD dalam pembentukan serta pembahasan peraturan desa.

3) Menempatkan kotak umpan balik di sebelah pintu masuk kantor kepala desa adalah cara lain bagi para pemimpin pemerintahan desa untuk mempelajari beragam harapan dan gagasan warga masyarakat untuk meningkatkan hasil mereka, serta untuk mempertimbangkan keinginan anggota masyarakat yang menginginkan perbaikan..

\section{Kesimpulan}

Adapun jabatan Kepala Desa dan BPD dalam pembangunan desa adalah sebagai berikut: a) Pengembangan Masyarakat berupa Pengembangan Masyarakat di Bidang Ekonomi, Pengembangan Masyarakat Desa di Bidang Hukum, Pengembangan Masyarakat di Bidang Agama, dan Pengembangan Masyarakat di Bidang Kesehatan . b) Menjadi Relawan dalam Komunitas c) Pertumbuhan komunitas. Selain itu, Aparatur Pemerintah Desa dan BPD telah berupaya memberikan dukungan yang terbaik kepada konstituennya di berbagai bidang sesuai dengan kapasitas dan kapabilitas yang telah ditentukan. Aparatur Pemerintah Desa memberikan pelayanan seperti meningkatkan taraf hidup masyarakat dengan meningkatkan pendapatan, menghubungi dan mendatangkan pelayanan pertanian dan kesehatan sebagai bentuk kepedulian terhadap berbagai permasalahan yang dihadapi warganya, dan bekerjasama dengan Fakultas Hukum Universitas Muhammadiyah Buton dalam kegiatan pelatihan penyusunan rancangan peraturan desa. Jenis layanan lain yang diberikan oleh ketua dewan desa adalah penempatan kotak umpan balik di pintu masuk kantor kepala desa, yang memungkinkan mereka untuk belajar tentang beragam aspirasi dan saran dari anggota masyarakat untuk lebih berhasil dan menghargai harapan masyarakat yang menginginkan adanya perbaikan.

\section{Daftar Pustaka}

Astuti, E. (2013). Akuntabilitas Pemerintahan Desa dalam Pengelolaan Anggaran Pendapatan dan Belanja Desa (APBDES) (Studi pada Alokasi Dana Desa Tahun Anggaran 2011 di Desa Sareng Kecamatan Geger Kab. Madiun). Public Knowledge Project (PKP), 1(2).

Dauwole, E., Kaawoan, J., \& Sendow, Y. (2017). Peran Badan Permusyawaratan Desa dalam Perencanaan Pembangunan. Eksekutif (Jurnal Jurusan IImu Pemerintahan), 2(2).

Roza, D., \& Arliman, L. (2017). Peran Badan Usaha Desa di Dalam Pembangunan Desa dan Pengawasan Keuangan Desa. Jurnal IImu Hukum (PJIH), 4(3).

Sadu Wasistiono, M., \& Tahir, M. I. (2007). Prospek Pengembangan Desa. Fokus Media.

Soekanto, S. (2003). Sosiologi Suatu Pengantar. Persada.

Sugiyono. (2010). Metode Penelitian Kuantitaif Kualitatif \& RND. Alfabeta.

Sunindhi, Y. W. (1996). Praktek Penyelengaraan Pemerintah di Daerah. Rineka Cipta. 
Surjadi, A. (1995). Pembangunan Masyarakat Desa. Mandar Maju.

Wijayanto, D. E. (2017). Kepala Desa dengan Badan Permusyawaratan Desa dalam Pembentukan Peraturan Desa. Jurnal Independent, 2(1). 